\title{
Yaşııııta Bağışıklık Sistemi, Pandemi ve Sosyal Hizmet Önerileri
}

\author{
Immune System, Pandemics and Social Work Advices in the Old Age
}

Tahir BELICE ${ }^{1}$, Selman BÖLÜKBAȘI ${ }^{2}$

\begin{abstract}
ÖZ
Yaşlanmanın en çok bilinen olumsuz sonuçlarından biri de immün sistemdeki zayıflama ve bunun sonucunda ortaya çıkan immün defisitler nedeniyle yeni veya daha önceden karşılaştığımız antijenlere hızlı ve etkili bir cevap verilememesidir. Yaşlanmanın immün sistem üzerine etkileri timus ve kemik iliğindeki B ve T hücreleri ve sekonder lenfoid dokulardaki olgun lenfositlerin fonksiyonlarının farklı düzeylerde azalması ile kendini belli eder. Bu nedenle yaşlı bireylerde bağ 1 şıklık sistemi herhangi bir tehdit karşısında kaldığında gençler kadar hızlı ve etkili bir immün cevap oluşturamamaktadır. Özellikle yaşlıların coronavirüs nedeniyle risk altında olduğu bir pandemi döneminde yaşlı çalışmalarının daha çok immün sistemdeki bu değişimler ve altta yatan moleküler olayların tanımlanması şeklinde planlanması ve belki de yaşlıların bağ 1 şıklık sisteminin desteklenmesi ile bu ve bundan sonraki olası viral salgınlarla etkili mücadele etmemizi sağlayabilecektir.

Derleme şeklinde yapılan bu çalışma, yaşlılığın sağlık boyutunu değerlendirirken yaşlilıkta meydana gelen immün sistem rahatsızlıklarına karşı alınabilecek önlemleri sosyal hizmet ilişkisiyle ayrıntılı bir şekilde irdeleyecektir. Bununla birlikte, bu çalışmanın merkezinde yer alan yaşlı yetişkinlerin refahını ya da yaşam kalitesini etkileyen faktörleri anlamak ileriki sosyal hizmet kuram ve çalışmalarına temel oluşturabilecektir.
\end{abstract}

Anahtar Kelimeler: Yaşl1,Pandemi,Coronavirüs,TLenfositler,Sosyal Hizmet

\begin{abstract}
One of the most well-known negative consequences of aging is the inability to respond quickly and effectively to new or previously encountered antigens due to the weakening of the immune system and the resulting immune deficits. The effects of aging on the immune system are manifested by the decrease in the functions of lymphocytes at different levels in $\mathrm{B}$ and $\mathrm{T}$ cells and secondary lymphoid tissues in the thymus and bone marrow. For this reason, when the immune system is faced with any threat in elderly individuals, they cannot create an immune response as fast and effective as young people. Especially in a pandemic period in which the elderly is at risk due to coronavirus, planning the elderly studies mostly through the identification of these changes in the immune system and the identification of the underlying molecular events. Perhaps by supporting the immune system of the elderly, we can enable us to effectively fight the coronavirus pandemic and possible next viral outbreaks. With this review, we will touch upon the differences in the immune system of the elderly and medical and social work that should be done during pandemic periods.
\end{abstract}

While this study, which is done in the form of a review, evaluates the health aspect of old age, it will scrutinize measures that can be taken against immune system disorders occurring in old age with the social work relationship in detail. However, understanding the factors affecting the well-being or quality of life of older adults, which are at the center of this study, may provide a basis for future social work theories and studies.

Keywords: Aged,Pandemics,Coronavirus,TLymphocytes,Social Work

\footnotetext{
${ }^{1}$ Tahir BELİCE, Dr, Dahiliye Uzmanı, İzmir Bozyaka Eğitim ve Araştırma Hastanesi, drtahirelf@ hotmail.com, ORCID: 0000-0001-7957-3423

2 Selman BÖLÜKBAŞI, Uzman Sosyal Çalışmacı, Manisa Aile, Çalışma ve Sosyal Hizmetler İl Müdürlüğü, selmanbolukbasi@yandex.com, ORCID: 0000-0003-3771-4827 


\section{GİRIŞ}

Tüm dünya, yaşlı popülasyonun sayısal ve oransal artıșı ile hızlı demografik bir paradigma kaymasını izlemektedir. ${ }^{1} \mathrm{Bu}$ da beraberinde güncel tıbbi, sosyal, ekonomik ve politik karar ve yaptırımların gündeme gelmesine neden olmaktadır. Yaşlanma hemen hemen bütün organ sistemlerinde hem hücresel hem de moleküler seviyede ortaya çıkan çok yönlü bir değişim sürecidir. $^{2} \quad$ Yaşlılığın en önemli değişimlerinden birisi ise artan otoimmünite, kronik düşük dereceli inflamasyon, artan kanser insidansları, aşılara yanıtın azalması, enfeksiyonlarla savaşma yeteneğimizde azalma vs. ile karşımıza çıkan immün sistemdeki hem yapısal hem de fonksiyonel değişimlerdir. ${ }^{3}$ Doğuştan ve kazanılmış immün sistemdeki hücre içi değişikliklerle beraber primer ve sekonder lenfoid organlardaki stromal mikro çevrenin yaşa bağlı gelişen bu immün disfonksiyonlardan sorumlu olduğu düşünülmektedir. İmmün sistemin normal fonksiyonları arasında enfeksiyonlarla savaşmak, malign veya otoreaktif hücrelerin tespit edilip yok edilmesi yer almaktadır. Bu derlememizde yaşlanma ile ortaya çıkan bağışıklık sistemimizin farklı komponentlerinde olan değişiklikleri irdelemeye çalışıp salgın hastalıkların yaşl1lık dönemindeki önemini vurgulamaya çalışacağız.

\section{İmmün Yaşlanma}

İmmün yaşlanmanın kliniksel sonuçları enfeksiyonlar, malignite ve otoimmün hastalıklar olarak karşımıza çıkmaktadır. Pnömoni ile influenza 65 yaş ve üstü hastalarda en s1k ilk 10 ölüm nedeni arasında yer almaktadır. ${ }^{4}$ Yaşı yetişkinlerde yine nozokomiyal enfeksiyonlar sıklıkla yüksek olup bu da yaşlanma ile ortaya çıkan immün fonksiyonlardaki zayıflama ve ek olarak yaşlı bireylerde aşıların sağlık açısından koruyucu etkilerinin azalmasinın bir sonucu olabilir. Ayrıca, bu immün defisitlerin yanında enfeksiyonların yaşlilarda ortaya çıkışını artıran kolaylaştırıcı faktörlerden de söz edilebilinir ki bunlar malnütrisyon, komorbid durumlar (diyabet, kronik obstrüktif akciğer hastalıkları, kalp yetmezliği, karaciğer sirozu gibi hastalıklar), mukoza bariyerlerin zayıflaması, öksürük refleksinin azalması ve diğer mekaniksel anatomik değişikliklerin (üriner sistem vs. gibi) varlığıdır. ${ }^{5}$

Yaşlilarda enfeksiyonların kliniksel özellikleri ve bulgu veren semptomları açısından incelendiğinde gençlere göre farklılıkların olduğu görülmektedir. ${ }^{6}$ Mesela şiddetli enfeksiyonlarda yaşlıların \%30'una kadarında ateş yanıtı oluşamayabilir. Yaşliların enfeksiyonlara verdikleri yanıtlar non-spesifik olup düşme, deliryum, anoreksiya veya genel düşkünlük hali gibi atipik semptomlarda prezente olabilmektedir. $^{6}$

Kanser insidans1 ve mortalitesinin 65 yaşlarından sonra artıp 90 yaşlarından sonra azaldığ1 bilinmektedir. Tümör hücrelerine karşı ilk savunmamız hem kazanılmış hem de doğuştan gelen immün sistem hücreleri ile yapılmakta olup primer veya kazanılmış immün yetmezlikli hastalarda kanser insidanslarının daha da fazla olması bu bulguları desteklemektedir. Fakat bununla birlikte karsinojenezis kompleks bir patolojik süreç olup immün yaşlanmanın tam olarak kanser gelişmesindeki rolünü belki de ileriki yıllarda anlayabileceğiz. Ama durum şu ki yaşlandıkça karsinojenlere maruz kaldığımız süre uzamakta ve yaşlanma ile mutant hücre yükümüz artmaktadır ve bu da malignensi gelişme riskini yaşlılarda artırmaktadır. ${ }^{7-8}$

Yaşlanma ile vücutta antikor üretiminde bir artış olduğu ve bir çalışmada sağlıklı bir yaşlıda antinükleer antikorun \%14, romatoid faktörün $\% 22$ ve antifosfolipid antikorlarının ise $\% 28$ oranında pozitif çıtığ 1 tespit edilmiştir. ${ }^{8} \mathrm{Bu}$ otoantikorların neden yaşlilarda üretiminin $\operatorname{arttığ}$ bilinmemekle beraber muhtemelen apoptotik hücre klirensinin azalmış makrofaj aktivitesi ile sekteye uğraması ve 

$\mathrm{T}$ hücre regülasyon fonksiyonlarında
defisitlerin gelişmesinin bir sonucu olarak söylenebilir. $\mathrm{Bu}$ nedenlerde romatolojik hastalıkların ileri yaşta laboratuvar ve kliniksel takip ve tedavilerinde atipik bulguların, özellikle enfeksiyon tedavi yönetiminde zorluklara neden olduğu bilinmektedir.

Yeterli ve dengeli beslenmek sağlıklı yaşlanmanın temel gerekliliklerinden birisini oluşturmakla birlikte yaşli popülasyonda maalesef yaşlanma ile malnütrisyon oranları ve ilgili komorbiditelerin insidansı önemli derecede artmaktadır. ${ }^{9}$ Yaşlanma ile artan kronik hastalıklar, fiziksel ve kognitif fonksiyonlarda azalmaya neden olarak gida ve sıvı alımına yönelimi içgüdüsel olarak azaltmaktadır. Kronik hastalıkların varlığında kullanılan ilaçların sayısı artarak, polifarmasi dediğimiz negatif sağlık sonuçları ile korelasyonu birçok çalışmada gösterilmiş klinik bir duruma neden olmaktadır. ${ }^{10}$ Polifarmasi nedeniyle yeme ve içme davranışlarımız bozulmakta ve malnütrisyon gelişmesi kaçınılmaz olmaktadır. Hatta kullanılan ilaçların yan etkilerinin yeni tanıların konulmasına ve yeni tedavilerin gündeme gelmesine neden olarak hastaları bir nevi reçete kaskatı dediğimiz kısır döngüye sokmaktadır. Sosyoekonomik kırılganlık da bir nevi yaşlılarda malnütrisyon oranlarının artmasina neden olarak enfeksiyon hastalıkları ile savaşımızda bizi olumsuz olarak etkilemektedir. ${ }^{11}$

Elimizdeki veriler ile vitaminler (A, D, $\mathrm{E}$, B6, B12, folat ve C) ve elementlerin (selenyum, çinko, bakır ve demir) normal immun fonksiyonları sürdürmek için gerekli olduğunu söyleyebiliriz, fakat bunların immün fonksiyonları artırdığına dair yeterli veri bulunmamaktadır. ${ }^{12-13}$ Ancak, yaşlanma ile bazal metabolizma hızının ciddi oranda azaldığı bilinmektedir ve bu da günlük hedeflenen kalori miktarında azalması ile sonuçlanır. $\mathrm{Bu}$ durumda daha az kalori alan yaşlıların beraberinde aldığı mikronutrient ile vitamin oranları da azalmaktadır. ${ }^{14}$ Net etki ise yaşlılar üzerinde sadece immün zayıflama değil diğer birçok fizyolojik süreçlerin olumsuz ilerlemesine neden olmaktadir. Örneğin magnezyumun vücutta 300'den fazla enzimin işlevinde etkili olduğu düşünülürse gıdalardaki vitamin ve elementlerin yeterli ve dengede alınmasının yaşlı sağlığı açısından önemi daha da iyi

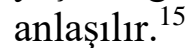

\section{Viral Salgın Hastalık Durumlarında Yaşlılar İçin Önerilebilecek Medikal Yaklaşımlar}

Özellikle risk altındaki bölgelerde, toplu yaşam alanlarında, savaş, doğal afet veya pandemik hastalık durumlarında çocuk ve kadınlar kadar yaşlıların da kırılgan ve desteğe ihtiyacı olduğu hatırlanmalıdır. Bu nedenle olası tehditler karşısında önceden araştırılarak belirlenmiş kriz yönetim protokollerinin etkin ve zamanında uygulanması önemlidir. Viral salgın dönemlerinde aşılanma programlarının yakın takip ile izlenmesi risk altındaki yaşlıların belirlenmesi ve aşılanmalarının yapılması kısmen de bağışıklık sistemi zayıf kırılgan olan yaşlılarda enfeksiyon hastalık gelișimini azaltabilir. İmmün yaşlanma ile gelen immün defektlerin ve zayıflıkların malnütrisyon, sosyoekonomik kırılganlık ve diyabet, kalp yetmezliği, astım ve KOAH gibi kronik hastalıkların varlığında daha da ciddi sağlık sorunlarına neden olabileceği hatırlanmalıdır. $\mathrm{Bu}$ nedenle viral salgın dönemlerinde yaşlı bireylerin yeterli ve dengeli miktarda yağ, karbonhidrat, protein, vitamin ve mikronutrient alımının olup olmadığ 1 tarama programları ile tespit edilip gerekli görüldüğü yerlerde müdahale edilerek patolojik sonuçların ortaya çıkması önlenebilir. Gerekirse kurumların ekonomik kırılganlığı tespit edilmiş yaşlılara maddi yardımda bulunması uygun olabilir.

Toplumda diyabet insidansının çok yüksek olduğu biliniyor ve kontrolsüz kan şekeri nedeni ile immün sistem fonksiyonlarının zayıflaması, diyabet hastalarının da kan şekerlerinin yakın takiple regüle edilmesini gerektirmektedir. 
hipertansiyona eğilim yaratan ve $\mathrm{ACE}$

Yine yaşlanma ile dehidratasyona eğilimin artmas1 nedeniyle günlük sıvı alımının yeterli düzeylerde olmasina dikkat edilmelidir. Yaşlilarda gereksiz yere diüretik kullanımı sorgulanarak tedavi modifikasyonlarının yapılması sağlanmalıdır. Yaşlıların viral salgın dönemlerinde, toplu mekanlarda kalmaması, sık sık el yıkamak gibi kişisel hijyene özen gösterilmesi, kıyafetlerin günlük temizlenmesi, yakın akraba ve arkadaş ziyaretlerinin minimuma indirilmesi gibi tedbirlerin alınması düşünülmelidir. Hasta bakıcıları ise sürekli yakın mesafede oldukları yaşlıların kompleks ve multiple hastalıkları nedeniyle enfeksiyon riski altındadırlar. $\mathrm{Bu}$ nedenle yakın temas halindeki bireylerin düzenli olarak hastalarla beraber pnömokok ve influenza aşılarını yaptırması önemlidir.

En son yaşadığımız Coronavirüs pandemisinde Çin'de hastaneye başvuranların yarısına yakınında hipertansiyon saptanırken bu oran İtalya'daki vakaların \%76'ını oluşturmaktadır. Ölen vakaların ise neredeyse tamaminda daha önce tanısı konmuş diyabet, kanser, astım, KOAH ve kardiyovasküler hastalık öyküsü olduğu tespit edilmiştir. Ağır ve fatal vakaların daha çok geriatrik yaş grubunda olması yaşlılar için özellikle özel bakım evleri gibi toplu yaşam yerlerinde özel önlemlerin alınması ve gerekirse salgın hastalık algoritmalarının oluşturularak krizin yönetilmesi düşünülmelidir. Salgın hastalıklarda etken patojenin fizyopatolojik ve klinik özelliklerin hızlı bir şekilde aydınlatılarak özellikli durumların analizlerle paylaşılması başarımızı artıracaktır. Daha önceki salgın hastalıklardan öğrendiklerimizi tekrar hatırlamalıyız ve her bir salgın hastalığın birbirine benzer ve birbirinden farklı epidemiyolojik ve klinik özelliklerinin olduğu hatırlanmalıdır. Örneğin kanamalı ateş yapan bir salgında kanama eğilimi yaratan ve kronik hastalıklarda kullanılan aspirin, kumadin vs. gibi ilaçların tekrar kar ve zarar dengesi düşünülerek tedavilerin güncellenmesi veya coronavirüs gibi inhibitörü, ibuprofen veya tiazolidindionlar gibi ajanlarla virüsün patojenitesinin arttığ 1 tespit edilen bir salgında tedavilerin gözden geçirilip modifiye edilmesi düşünülebilinir.

\section{Viral Salgın Hastalık Durumlarında Yaşlı Bakım Kuruluşları ve Önerilebilecek Sosyal Hizmet Yaklaşımları}

Yaşlı bakım kuruluşları, birden fazla yaşlıların toplu olarak barındıkları ev tipi ya da kurum tipi sosyal hizmet kuruluşlarıdır. $\mathrm{Bu}$ kuruluşların yaşlılar ve personel için alınabilecek önlemler vardır ve bunlar şöyledir:

- Bütün yaşlı bakım kuruluşlarına kesinlikle yeni bir yaşlı kabulü yapılmaması ve mülki idare amirlerce ara istasyonların belirlenmesi gereklidir.

- Terk, buluntu, sığıntı, acil vakalar ve hastanelerden taburculuk sonrası doğrudan sosyal hizmet kuruluşlarına kabul edilmemesi, bu ara istasyonlarda 14 gün izolasyon uygulamasından sonra kabulün sağlanması önemlidir.

- Bütün kuruluşlarda yaşlıların ve personelin dört saatte bir günde 6 defa ateşleri ölçülmeli, günlük tansiyon takiplerinin yapılmalı ve bunlar takip çizelgelerine işlenmelidir.

- Kuruluşlarda hareketli unsurun personel olduğu unutulmamalı, on beşer günlük sabit yatılı vardiyalara geçilmeli ve personellerin sabit görev yerleri belirlenmelidir.

- Personel vardiya değişimlerinde yeni gelen personel hekim kontrolünden geçirilmelidir.

- Herhangi bir 38 derece ateşte ya da tansiyonda görülen anormal değişikliklerde sağlık kuruluşlarıyla doğrudan irtibata geçilmeli, acil vakalar dışında yaşlılar sağlık kuruluşlarına gönderilmeden yaşlı bakım kuruluşlarına hekim görevlendirilmelidir.

- Sağlık kuruluşlarına giden yaşlıların yeniden kabulü yapılmamalı, hastanelerin 
işlevsel kullanılmasının gerekli olduğu durumlarda, izole kuruluşlar, ek binalar ya da sağlik konteynerlerinde barındırılmalıdır.

- Kuruluş odaları her iki saatte bir onar dakika havalandırılmalıdır.

- Yaşliların yemekleri odalarında verilmeli, yemekten sonra odalar havalandırılmalıdır.

- Kuruluşta kalan yaşlilara psikososyal destek sağlanmalı ve odalarında yapabilecekleri hobi malzemeleri ve uygulamaları temin edilmesi gereklidir.

- Personelin evlerine teslimi kuruluş araçlarınca yapılmalıdır.

- Yurtdişından veya İl dışından gelen personel ya da personelin yurtdışından veya İl dişından gelen bir kişiyle irtibatlı olması halinde 14 gün evde izolasyonu sağlanmalıdır. ${ }^{16}$

- Dişarıdan gelen personelin doğrudan personel odasına giderek ayakkabıları dahil kıyafetlerini değiştirmesi, personel odasının giriş kapısına yakın bir yerde bulunması gereklidir.

- Kesinlikle dişarıdan ziyaretçi kabul edilmemelidir. Diș kurumlardan gelen kamu görevlilerinin ise yaşlılarla irtibat kurmasından kaçınılmalıdır.

- Kuruluş binası ve hizmet araçlarının dezenfeksiyonu için kullanılacak solüsyon muhakkak virüslere karşı etkin maddeleri (etil alkol, hidrojen peroksit, iyot vb.) içerir olmalidir.

- $\mathrm{Bu}$ süreçte yaşlı yakınlarıyla yaşlılar arasinda video konferans ya da telefon yoluyla irtibat kurmasının sağlanması yaşlılar için iyi bir psikososyal destek olacaktır.

- Ayrica kuruluşta görevli psikolog ve sosyal hizmet uzmanlarınca yaşlıların psikolojik durumlarının değerlendirilerek uygun sosyal hizmet modelleri uygulanmalıdır. $\mathrm{Bu}$ süreçte meslek elemanlarının yaygın anksiyet yaklaşımı ağırlıklı çalışmaları faydalı olacaktır.

\section{SONUÇ VE ÖNERILLER}

$\mathrm{Bu}$ derlememizde yaşlı hastaların immün sistemlerindeki farklı özelliklerine ve salgın hastalıklarda izlenebilecek stratejik yaklaşımlara kısaca değinmek istedik. Yaşlıların salgın hastalıklar gibi kritik dönemlerde gerek medikal gerekse sosyal hizmet programları ile desteklenerek koruma altına alınması ile toplum olarak bilgi ve deneyim sahibi bu koca çınarların gölgesi altında sağlam ve emin adımlarla gelecek kuşaklara daha güzel bir dünya bırakabiliriz. $\mathrm{Bu}$ bağlamda toplumda her kesimin yaşlı bilincine sahip olması için gerek sosyal medya ve yayın organları gerekse kırsal ve kentsel bölgelerde yüz yüze farkındalık çalışmalarının yapılması akılcı olacaktır.

\section{KAYNAKLAR}

1. United Nations. (2013). World Population Ageing 2013. Department of Economic and Social Affairs, Population Division. New York: United Nations Publication.

2. Khan, S. S., Singer, B. D., \& Vaughan, D. E. (2017) "Molecular And Physiological Manifestations and Measurement of Aging in Humans". Againg Cell, 16 (4), 624 633. https://doi.org/10.1111/acel.12601

3. Ponnappan, S., \& Ponnappan, U. (2011). "Aging and immune function: molecular mechanisms to interventions". Antioxidants \& Redox Signaling, $14 \quad$ (8), 1551-1585. https://doi.org/10.1089/ars.2010.3228

4. U.S. Department of Health \& Human Services. (2020). "Ten Leading Causes of Death and Injury. Center for Disease Control and Prevention": https://www.cdc.gov/injury/wisqars/LeadingCauses.html adresinden alınd
5. Gavazzi, G., \& Krause, K. H. (2002). "Ageing and Infection". Lancet Infect Dis., 2 (11), 659-66. https://doi.org/10.1016/s1473-3099(02)00437-1.

6. Norman, D. C. (2000). "Fever in the Elderly". Clin. Infect Dis., 31(1), 148-151. https://doi.org/10.1086/313896

7. Malaguarnera, L., Cristaldi, E., \& Malaguarnera, M. (2010). "The Role of Immunity in Elderly Cancer". Crit Rev Oncol Hematol., 74 (1), 40-60. https://doi.org/10.1016/j.critrevonc.2009.06.002

8. Ramos-Casals, M., Brito-Zerón, P., López-Soto, A., \& Font, J (2004). "Systemic Autoimmune Diseases in Elderly Patients: Atypical Presentation and Association with Neoplasia". Autoimmun Rev., 3 (5), 376-82. https://doi.org/10.1016/j.autrev.2003.12.002 
9. Volkert, D., Beck, A. M., Cederholm, T., Cereda, E., CruzJentoft, A., Goisser, S., de Groot, L., Großhauser, F., Kiesswetter, E., Norman, K., Pourhassan, M., Reinders, I., Roberts, H. C., Rolland, Y., Schneider, S. M., Sieber, C. C., Thiem, U., Visser, M., Wijnhoven, H., \& Wirth, R. (2019). "Management of Malnutrition in Older Patients-Current Approaches, Evidence and Open Questions”. J Clin Med., 8(7), 974. https://doi.org/10.3390/jcm8070974

10. Seyede, S. M., Mohsen, S., Abasali, K., Seyed Kazem, M. Mohsen, B., \& Shervin, A. (2016). "Defining Polypharmacy in the Elderly: a Systematic Review Protocol”. BMJ Open, 6 (3), $1-4$

11. Hoogendijk, E. O., Flores Ruano, T., Martínez-Reig, M., López-Utiel, M., Lozoya-Moreno, S., Dent, E., \& Abizanda, P. (2018). "Socioeconomic Position and Malnutrition among Older Adults: Results from the FRADEA Study". J Nutr Health Aging. 22 (9), 1086-1091. https://doi.org/10.1007/s12603-0181061-1

12. Maggini, S., Wintergerst, E., Beveridge, S., \& Hornig, D. (2007). "Selected Vitamins and Trace Elements Support Immune Function by Strengthening Epithelial Barriers and Cellular and Humoral Immune Responses". Br J Nutr., 98 (1), 29.

13. Chandra R. K. (2004). "Impact of nutritional status and nutrien supplements on immune responses and incidence of infection in older individuals". Ageing Res Rev., 3 (1), 91-104. https://doi.org/10.1016/j.arr.2003.08.004

14. Pray, L., Boon, C., Miller, E. A., \& Pillsbury, L. (2010). Providing Healthy and Safe Foods As We Age: Workshop Summary. The Institute of Medicine, National Academies, Food and Nutrition Board. Washington, D.C.: The National Academies Press.

15. Jahnen-Dechent, W., \& Ketteler, M. (2012). "Magnesium basics". Clin Kidney J, 5 (1), i3-i14 https://doi.org/10.1093/ndtplus/sfr163

16. Australian Government Department of Health. (2020). "Coronavirus (COVID-19) Information for Health Care and Residential Care Workers". Mart 22, 2020 tarihinde Australian Government Department of Health: https://www.health.gov.au/sites/default/files/documents/2020/0 3/coronavirus-covid-19-information-for-health-care-andresidential-care-workers_4.pdf adresinden alındı 